\title{
FELMÉRÉS TROLIBUSZVEZETŐK KÖRÉBEN A HIBRID TROLIBUSZOKRÓL
}

\author{
Gál József - Tóth István Tibor
}

\begin{abstract}
Absztrakt: Városiasodó világunkban mindig fontos feladat volt a helyi közlekedés hatékony, gazdaságos, fenntartható kialakítása, megvalósítása. A fenntarthatóság alatt napjainkban szinte mindenki a környezetbarát, energiahatékony megoldások alkalmazását érti. Manapság általánosan elfogadott szemlélet az egyéni közlekedést kiváltó elektromos hajtású közösségi közlekedés, kerékpározás, gyaloglás, carsharing és e-autózás fejlesztése. A lakosság számával és életmódjának változásával bövülö egyéni utazások száma miatt egyre nehezebb olyan megoldást ajánlani, ami korunk emberének megfelel. Szegeden, a településszerkezet, az épített közlekedési infrastruktúra, a kialakult kötöttpályás hálózat, mind sugallja az elektromos meghajtású jármüvek használatának bővítését. Az elektromos jármüvek térhódításának lehetőségét két irányban vizsgálja az Európai Unió által támogatott H2020-as ELIPTIC projekt. Az egyik irány a trolibusz vonalak bövítése, meghosszabbítása felsővezeték építése nélkül, az autóbusszal végzett szolgáltatási arány kárára. A másik irány a meglévő infrastruktúrára épülő multifunkcionális elektromos töltő hálózat kiépítése. Több cikkböl álló publikációnkban trolibuszvezetőket kérdeztünk meg kérdőíves módszerrel a témában kialakult véleményükröl.
\end{abstract}

Abstract: In our urbanizing world has always been an important task the design and implementation of an efficient, economical, sustainable local transport system. Under the sustainability Today, almost everyone understands the environmentally friendly use of energy-efficient solutions, which are alternatives to private transport electric public transport, cycling, walking, car-sharing and e-car was driving the generally accepted approach. Due to increasing population and changes of lifestyle, expands the number of individual trips and ever more complex to offer a solution that meets the man of our time. In Szeged, the settlement structure, the built transport infrastructure, the track-developed network, all suggest the expansion of the use of electric vehicles. The possibility of penetration of electric vehicles examines in two directions the H2020's ELIPTIC project funded by the European Union. One of the directions is the expansion, extension of trolleybus lines without the overhead construction reducing the rate by coach and bus services. The other direction to build a multifunctional electric charger network based on the existing infrastructure. We asked trolleybus drivers by questionnaire about their opinions.

Kulcsszavak: hibrid trolibuszok, fenntartható helyi közlekedés, közösségi közlekedés, elektromos infrastruktúra, ELIPTIC

Keywords: hybrid trolleybuses, sustainable local transport, public transport, electrical infrastructure, ELIPTIC

\section{Bevezetés}

$\mathrm{Az}$ ELIPTIC projekt keretében készült kérdőíves felmérés eredményeinek értelmezése kapcsán felmerült annak kérdése, hogy maguk a megkérdezettek, aktívan dolgozó (17 fö) trolibuszvezető, mint utas hogyan ítéli meg a korábban utasoknak feltett kérdések egy részét. Ebben az esetben fontos volt, hogy egy meglévő autóbuszvonal környezetet kevésbé terhelö üzemeltetése, milyen hatással lehet Szeged levegöjének tisztaságára, mennyiben fontos e szempont az utasok, illetve a lakosság számára? A kiválasztott $77 \mathrm{~A}$ autóbuszjárat a városközpontot köti össze Szeged egyik elövárosával (Baktó, Völgyérhát u.). A járat kombinálva közlekedik a 77 jelzésü járattal - jellemzően -óránként kétszer, 77A és egyszer 77 
járatként. A 77-es járat meghosszabbított útvonalon Szeged személypályaudvarig (Indóház tér) megy el.

\section{Szakirodalmi áttekintés}

Szakmai terminológiai viták folynak arról, hogy a trolibuszok hibrid változatának megjelenésével az önjárásra is képes jármüvek kötöttpályás közlekedésnek tekintendők van már nem? A tömegközlekedési, napjainkban inkább közösségi közlekedési eszköznek nevezett jármüvek között ezért különleges helyet foglal el a trolibusz, amely egy közúton közlekedő villamosjármünek volt tekinthető az utóbbi évekig. Napjainkban azonban egyre nagyobb teret nyernek a hibrid jármüvek, melyek között találhatók diesel-elektromos és felsővezetékes-akkumulátoros változatok is. Szeged esetében az utóbbi típusokból került beszerzésre 13 darab, melyeket sokkal több célra lehetne használni, mint ezidáig történt. Alapvetöen azonban megjelenésében inkább egy autóbuszhoz hasonlít, gyakran felépítménye azonos, de villamos hajtásában és felsővezetékhez kötöttsége miatt a villamossal is rokonságot mutat. Klasszikusan pályához kötöttnek nem nevezhetö, azonban a felsővezeték útvonalát általában nem hagyja el, csupán a korábban említett hibridek esetében lehet róla szó.

Napjainkban a közlekedés által okozott környezeti ártalmak tekintetében a trolibusz, valamennyi felszíni közlekedési eszköz közül a legjobb helyet foglalja el. Ha a levegőt szennyező mértékre vetítjük teljesítményét, akkor - más közösségi közlekedési jármüvekkel összehasonlítva - még kedvezöbb értékekről beszélhetünk. A felszíni zaj és rezgés szempontjából is a trolibusz a legkörnyezetkímélöbb eszköz, gyorsítási és elhaladási zaja az autóbusznál és a villamosnál is kisebb (Nagy-Szabó, 1984; Bajusz, 1975, www.kvvm.hu/cimg/documents/_7_VKK_T_zisei.doc 2016.12.10.; http://www.alternativenergia.hu/tag/szeged/page/3 2016.10.13.; http://iho.hu/hir/trolikalandozasok-transznisztriaban-160808 2016.09.27.; http://www.autoszektor.hu/hu/content/onvezeto-jovobusz-mercedestol

2017.10.29.). Külön figyelemre méltó a hibridek zajkibocsátása, ahol még az áramszedök által keltett zaj is elmarad akkumulátoros üzemmódban.

Bármennyire jónak tekinthetők az objektív müszaki-gazdasági mutatók, nagyon fontos, hogy az általuk nyújtott szolgáltatást igénybe vevők megelégedettségére teljesítsék feladatukat. Mindenki számára világos, hogy a közösségi közlekedés hatékony és az utazási keresletet elvárható színvonalon kielégítő megoldása nagyon sok szervezőmunkát, odafigyelést, igényes feladatvégrehajtást igényel, melynek egy része az utasok előtt mindvégig láthatatlan marad. Nem elegendỏ a jármủ, a pálya, az energiaellátás biztonsága, karbantartása, a szolgáltató személyek felkészültsége, hozzáállása is elengedhetetlen.

\section{A gépkocsivezetők körében végzett felmérés eredményei}

Az első kérdés esetében máris jelentős eltérés mutatkozott, hiszen a soförök speciális réteget képeznek, amikor utasként közlekednek. Nem szabad figyelmen kívül hagyni, hogy müszakkezdés elött korán reggel vagy az éjszaka befejeződö 
munkavégzés miatt éjjel érik el otthonukat vagy reggel az indulási telephelyet. Ekkor még a közösségi közlekedés járművei nem közlekednek, így 19\% tesz említést kerékpárról, $12 \%$ személyautóról, 7\% motorbicikliről (az utóbbi kettő az utasok között nem volt jellemzö), még említésre méltó a gyaloglás (a telephely és a közeli lakótelep adhat erre magyarázatot), és - vélhetően a müszakváltásoknál - a trolibusz $31 \%$-kal jelenik meg.

Ha a közösségi(tömeg)közlekedést választotta, annak elönyei tekintetében nagy eltérés nem mutatkozik (1. ábra) $42 \%$ esetében a gyors eljutás nagyon fontos tényezö, de a járatsürüség ( $21 \%$ ) és a közvetlen elérés viszonylag magas arányú megemlítése összhangban áll a korábbi, általános utasfelmérés eredményeivel.

A trolibuszvezetők fele-fele arányban szállnak át utazásaik során, melyből messzemenő következtetést nem lehet levonni. A vizsgált vonallal kapcsolatban sem lehet konzekvens eredményt levonni, hiszen a megkérdezett soförök (a „Milyen gyakran utazik a 77-es vagy 77/A autóbusz vonalakon?" - kérdésre) egyöntetúen azt a választ adták, hogy a vonalat nem használják, tehát a járatra beosztott soför és annak használója között nincs összefüggés.

\section{1. ábra: Szükségesnek tartja-e Szegeden az autóbuszok önjáró trolibuszokkal történő kiváltását egyes vonalak módosításával?}

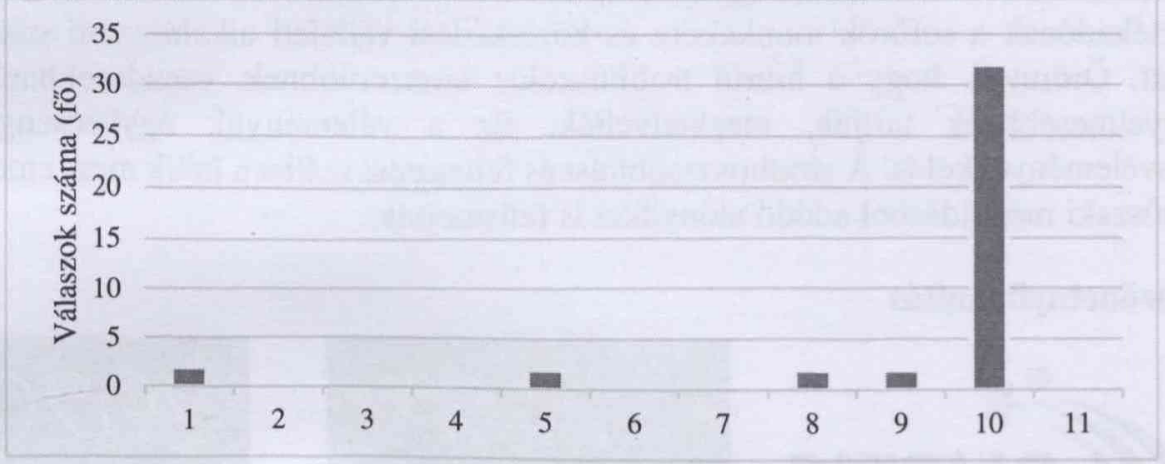

Forrás: ELIPTIC felmérés (2016)

Örömteli viszont a „Mennyire fontos Önnek, hogy Szeged levegőszennyezettsége alacsony szintü legyen?" kérdésre 100\%-ban adott pozitív válasz, amely a cég alkalmazottjaiban kialakított környezettudatosságra utal.

Érzékel-e különbséget utaskényelmi szempontból az autóbusz, illetve a most használt trolibusz között? A gépjárművezetők egyöntetüen csendesebbnek és kényelmesebbnek tartják ezeket a modelleket, amely egybecseng a korábban megkérdezett utasok véleményével is, akik - ha nem is $100 \%$-ban - de döntő többségükben ugyanúgy gondolták. A kerékpár fuvarozására trolibuszon az utasigény sem igazán jelent meg, a sofőrök pedig elutasították az ilyen irányú fejlesztést. A menetjegy típusára vonatkozó kérdésnek nem volt túl sok értelme, hiszen az SZKT dolgozói szabadjeggyel utaznak munkakörükből adódóan.

A trolibuszvezetők meghatározó többsége szükségesnek tartja, viszont nem csupán azért, hogy az adott hálózat meghosszabbítható legyen, hanem egyes 
forgalmi szituációkban (pl. torlódás, baleset esetén) a lezárt helyszín alternatív úton kikerülhető, így az eljutási idő nem hosszabbodik meg jelentősen. A forgalom- és járattervezés során is könnyebbséget jelentene a felsővezetékek közötti átjárhatóság olyan helyeken, ahol ez nincs kiépítve. Egy tesztüzemet követően - felsővezeték kiépítés nélkül, amely hosszadalmas hozzájárulási, engedélyeztetési folyamat eredménye lehet - eldönthető, kell-e egyáltalán a kiépítés?

„Mennyire támogatná Szeged trolibusz hálózatának bővítését?” - szólt a következő kérdés, melyet a sofőrök - 1 fö kivételével - egyöntetüen javasolnak. Az említett 1 fö is egyetért, de nem teljes egészében.

Előnyben részesíti-e a környezetbarát elektromos közösségi közlekedési eszközöket?" - is szinte egyértelmủ támogatottságot élvez, csak 1 fó érzi úgy, hogy számára nincs jelentősége. Egy későbbi kérdőíves felmérésünkben az elektromos személyautók használatának megítélésével kapcsolatban is tettünk fel kérdést, amely a következő tanulmányunk témáját jelenti.

\section{4. Összefoglalás}

A trolibuszvezetők körében végzett kérdőíves felmérés kérdései megegyeztek a korábban utasok körében végzett felméréssel. Tanulságos eredmények születtek, viszont ki kell azt is emelni, hogy több kérdésre adott válasz esetében nem tekinthető mértékadónak a soförök munkaköre és közlekedési vállalati alkalmazotti státusza miatt. Örömteli, hogy a hibrid trolibuszokat korszerübbnek, csendesebbnek és kényelmesebbnek tartják, megkedvelték. Ez a véleményük egybecseng az utasvéleményekkel is. A járathosszabbítást és fejlesztést reálisan ítélik meg, emellett a müszaki megoldásból adódó előnyöket is felismerték.

\section{Köszönetnyilvánítás}
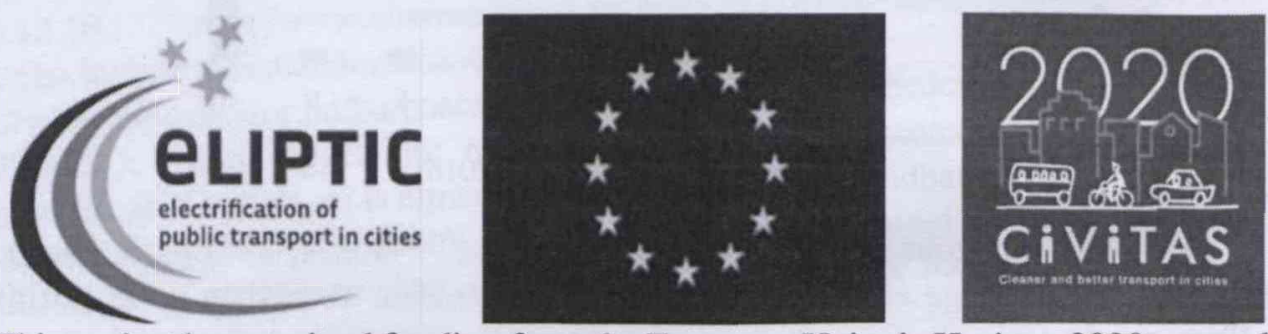

This project has received funding from the European Union's Horizon 2020 research and innovation programme under grant agreement No 636012.

\section{Irodalomjegyzék}

Bajusz R. (1975): Személyközlekedésünk ma és holnap. Kossuth Kiadó, Budapest.

Nagy E., Szabó D. (1984): Városi közlekedési kézikönyv. Müszaki Könyvkiadó, Budapest.

sz. n. (2016): Önvezető jövőbusz a Mercedestől. 2016.07.30. <http://www.autoszektor.hu/hu/ content/onvezeto-jovobusz-mercedestol> (2017.10.29.)

sz.n. (2016): Városi Közlekedéspolitikai Koncepció Tézisei. <www.kvvm.hu/cimg/documents/ _ 7 _VKK_T_zisei.doc> (2016.12.10.)

sz.n. (2013): Önjáró trolibuszt mutattak be Szegeden. <http://www.alternativenergia.hu/tag/ szeged/page/3> (2016.10.13.) 
sz.n. (2016): Trolikalandozások Transznisztriában. 2016.08.08. <http://iho.hu/hir/ trolikalandozasoktransznisztriaban-160808> (2016.09.27.) 